\title{
Remedial Work Assessment to Prepare an Autistic Child for School*
}

Evaluación del trabajo remedial para preparar a un niño autista para la escuela

Avaliação do trabalho corretivo para preparar uma criança autista para a escola

\author{
Anna Vinevskaya** iD orcid.org/0000-0001-8797-6281 \\ Irina Burshit ${ }^{* * *}$ iD orcid.org/0000-0001-6811-7107 \\ Evgeny Lopatkin**** iD orcid.org/0000-0002-8408-1789
}

Para citar este artículo: Vinevskaya, A., Burshit, I. y Lopatkin, E. (2021). Remedial Work Assessment to Prepare an Autistic Child for School. Revista Colombiana de Educación, 1(81), 123-146. https://doi.org/10.17227/ rce.num81-10521

\section{(c) (i) (8)}

* $\quad$ The study was carried out with the financial support of the RFBR [Russian Foundation for Basic Research] as part of the research project "Understanding the Socio-Philosophical Phenomenon of Educational Inclusion in the Context of Foreign and Domestic Methodological Approaches and Models," No. 19-013o0I17 19. Grant Director Oksana Anatolyevna Musika, Doctor of Philosophy, Professor.

** Candidate of Pedagogical Sciences. Associate Professor of the Department of General Pedagogy of the Faculty of History and Philology A.P. Chekhov Taganrog Institute (branch) of Rostov State University of Economics (RSUE), Russia, Taganrog. E-mail: vinevskaya.rsue@bbr.ru

*** Candidate of Pedagogical Sciences. Associate Professor of the Department of General Pedagogy of the Faculty of History and Philology Chekhov Russia. E-mail: burshit.rsue(aro.ru

**** Candidate of Pedagogical Sciences, Associate Professor of the Department of General Pedagogy of the Faculty of History and Philology A.P. Chekhov Taganrog Institute (branch) of Rostov State University of Economics (RSUE). E-mail: lopatkin.rsue@ro.ru 


\begin{abstract}
This article focuses on remedial work aimed at developing skills in autistic children to prepare them for school, which involves organizing interactions within the triad child - parents - teaching staff. The purpose of the study is to determine the effectiveness of interactions with an autistic child as a result of remedial work during the preschool period. The observational method allowed us to map the psychological and pedagogical characteristics of a first-grader, whereas the journal method allowed us to assess remedial work. A social and communication skills assessment showed that $28 \%$ of skills partially manifested at the beginning and end of the school year, $36 \%$ of skills had a partial manifestation dynamic, and $36 \%$ of skills were undeveloped. A hygiene and self-care skills assessment showed the partial manifestation of $38.9 \%$ of skills without a dynamic and $61.1 \%$ of skills with dynamic. These assessments revealed that $50 \%$ of academic skills do not show dynamics, whereas $33.3 \%$ do, and $16.7 \%$ are undeveloped. An organizational and behavioral skills assessment demonstrated $65.2 \%$ undeveloped skills, whereas $34.8 \%$ of skills are defined as partially developed. The results obtained confirm the effectiveness of the interactions within the triad after remedial work, since a dynamic was observed in $40.54 \%$ of all partially developed skills.
\end{abstract}

\section{Keywords}

autism spectrum disorder; remedial work; preparation for school; journal method; assessment

\section{Palabras clave}

trastorno del espectro autista; trabajo remedial; preparación para la escuela; bitácora; evaluación

\section{Resumen}

Este artículo se centra en el trabajo remedial dirigido a desarrollar habilidades en niños autistas para prepararlos para la escuela, lo cual implica planear interacciones dentro de la tríada: niño - padres - personal docente. El propósito del estudio es determinar la efectividad de las interacciones con un niño autista como resultado del trabajo remedial durante el período preescolar. La observación nos permitió mapear las características psicológicas y pedagógicas de un alumno de primer grado, mientras que la bitácora nos permitió evaluar el trabajo remedial. Una evaluación de las habilidades sociales y de comunicación mostró que el $28 \%$ de las habilidades se manifestaron parcialmente al principio y al final del año escolar, el 36\% de las habilidades tenían una dinámica de manifestación parcial y el 36\% de las habilidades no estaban desarrolladas. Una evaluación de habilidades de higiene y autocuidado mostró la manifestación parcial de 38,9\% de habilidades sin dinámica y $61,1 \%$ de habilidades con dinámica. Estas evaluaciones revelaron que el 50\% de las habilidades académicas no muestran dinámica, mientras que el 33,3\% sí y el $16,7 \%$ están subdesarrolladas. Una evaluación de habilidades organizativas y de comportamiento demostró un $65,2 \%$ de habilidades no desarrolladas, mientras que el 34,8\% de las habilidades se definen como parcialmente desarrolladas. Los resultados obtenidos confirman la efectividad de las interacciones dentro de la tríada después del trabajo correctivo, ya que se observó una dinámica en el 40,54\% de todas las habilidades parcialmente desarrolladas.

\section{Resumo}

Este artigo concentra-se no trabalho corretivo que visa desenvolver habilidades em crianças autistas para prepará-las para a escola, o que envolve o planejamento de interações dentro da tríade: criança - pais - professores. O objetivo do estudo é determinar a eficácia das interações com uma criança autista como resultado do trabalho corretivo durante o período pré-escolar. A observação permitiu mapear as características psicológicas e pedagógicas de um aluno da primeira série, enquanto o diário de bordo permitiu avaliar o trabalho corretivo. Uma avaliação das habilidades sociais e de comunicação mostrou que $28 \%$ das habilidades se manifestaram parcialmente no início e no final do ano letivo, 36\% das habilidades tiveram dinâmica parcial de manifestação e 36\% das habilidades não foram desenvolvidas. Uma avaliação das habilidades de higiene e autocuidado mostrou a manifestação parcial de 38,9\% de habilidades sem dinâmica e 61,1\% de habilidades com dinâmica. Essas avaliações revelaram que 50\% das competências acadêmicas não apresentam dinâmica, enquanto 33,3\% apresentam e 16,7\% são subdesenvolvidas.

N. ${ }^{\circ} 81$ Uma avaliação das habilidades organizacionais e comportamentais mostrou 65,2\% das habilidades não desenvolvidas, enquanto 34,8\% das habilidades são definidas como parcialmente desenvolvidas. Os resultados obtidos confirmam a eficácia das foi observada em 40,54\% de todas as habilidades parcialmente desenvolvidas.

\section{Palavras-chave}

transtorno do espectro do autismo; trabalho corretivo; preparação para a escola; diário de bordo; avaliação 


\section{Remedial Work Assessment to Prepare an Autistic Child for School}

Preparing senior preschool age children for school at a general education organization (hereinafter - school) is an important step in developing their personalities, motivations, and abilities. Currently, the issue of working with children with special educational needs (SEN) during the preschool period is particularly pressing. In Russia, this is regulated by the Federal State Educational Standard for Preschool Education (FSES PE), in which SEN is understood as "the individual needs of a child related to their life situation and health conditions, determining their need for special conditions when receiving an education" (FSES PE, 2013, p. 37).

Science is interested in SEN when a child has autism spectrum disorder (ASD) as a disease associated with impaired neurological development during childhood. As a result of this condition, cognitive functions are depressed and creative abilities are reduced (Abidoğlu, et al., 2017, p. 4959). These children also have an insufficient level of social interaction (Boekhof, et al., 2015, p. 2035), together with a lower level of emotional expression (Teh, et al., 2018, p. 4138) and behavioral restrictions (Anderson, et al., 2018, p. 4). These disorders in children with ASD, or autistic children, can be mitigated by timely remedial work that allows them to function in society.

The timely organization of remedial work with autistic children during the preschool period implies a system of special measures aimed at overcoming or weakening disadvantageous personality developments that impede schooling. Children with autism need "an individualized program of assistance and guidance adjusted to their personal characteristics" (Dovbnya, et al., 2018, p. 11). In this regard, there is a need for an Adjusted Model of a General Basic Education Program for Preschool Students with children with ASD. However, that program has not been officially developed in Russia, in contrast to the similar program for a general primary education system approved in 2015.

Education Adjustment Programs (EAPS), independently developed by Preschool Educational Institutions (PEIS), are incomplete due to the incompatibility of some FSES PE provisions with scientific research. Representatives of the Academy of Vocational Education in Lipetsk also mention the absence of official methodological developments for teaching remedial and combined groups of no more than five autistic children over the age of three years (Academy of Professional Development, 2018). Constant remedial work with autistic children should be the main focus of PEIS because the education is individualized and techniques and methods are adjusted considering students' SEN to master educational material

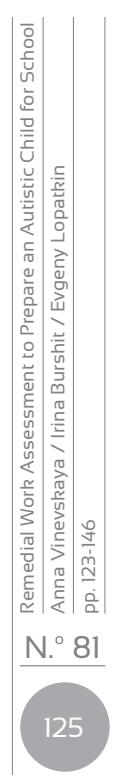


in the classroom. It also achieves their remedial potential. Particularly, during the preschool period, conditions need to be created for these children to develop cognition and increase their level of social interaction. Such conditions should include interactions between the key figures of the child's education: other children, parents, legal guardians, or closest adults (hereinafter referred to as parents), as well as pedagogical workers, including psychologists, pathologists, and speech therapists. Timely remedial work with autistic children during the preschool period should involve organizing constant interactions within this triad, with the purpose of building the skills necessary for further schooling. Thus, the scientific problem in the preschool education system in question, is how to organize this kind of interactions.

Interaction are individualized because of the peculiarities in the neurological development of children with ASD. This makes it advisable to consider interactions within the triad individually for each child, allowing methods to be extrapolated to form the skills needed for school and to organize interactions with other autistic children, whose neurological development disorders vary greatly. These disorders include cognitive distortion and affective-emotional distortion, for which each child with ASD manifests individualized behavioral patterns.

This scientific problem allows us to formulate the purpose of the study, namely: determine the effectiveness of the interactions with an autistic child after remedial work during the preschool period. This goal gives rise to the research hypothesis: analyzing the skills exhibited as a result of remedial work with an autistic child during the preschool period will determine how the effectiveness of the interactions with them is organized.

\section{Literature Review and Analysis}

The SEN of a child diagnosed with ASD must be considered during the process of preparing them for school. The need for early remedial work and the provision of specialized educational services is indicated by the American researchers from the University of Oregon L. L. McIntyre and P. $K$. Zemantic, who associate these services with an early recognition of the disease (McIntyre \& Zemantic, 2017, p. 727). This opinion is supported by a group of Japanese researchers who believe that the early introduction of remedial work helps to improve the overall development of an autistic child, correct their behavior, and reduce the onset of ASD symptoms (Tachibana, et al., 2017, p. 2). According to the theorist from Moscow, G.V. Don, the development of these preschoolers at PEIS is preferable in all-day groups or short-term stay groups, considering behavior disorders, as well as receptive and expressive speech (Don, 2017, p. 17). 
The main areas of remedial work with an autistic child during the preschool period fall into the following educational areas: social and communicative development, cognitive development, speech development, artistic and aesthetic development, and physical development (Training and Methodological Center, 2018). The objectives of remedial work by area were analyzed by the authors of this article based on EAPS implemented mainly at PeIs in Krasnodar, Moscow, Pskov, Tyumen (Training and Methodological Center, 2018), and Maykop (General Development Kindergarten No. 11, 2016), see Table 1.

\section{Table 1}

Remedial Work with an Autistic Preschooler

\begin{tabular}{|c|c|}
\hline $\begin{array}{l}\text { Educational field } \\
\text { of remedial work }\end{array}$ & Goal of remedial work \\
\hline $\begin{array}{l}\text { Social and } \\
\text { communication } \\
\text { development }\end{array}$ & $\begin{array}{l}\text { Socialization, development of communication, moral education } \\
\text { The child in the family and society, patriotic education } \\
\text { Self-care, independence, vocational education } \\
\text { Laying the foundation for security }\end{array}$ \\
\hline Cognitive development & $\begin{array}{l}\text { Development of elementary mathematical understanding } \\
\text { Development of cognitive research abilities } \\
\text { Familiarization with the subject and social environment } \\
\text { Familiarization with the world of nature }\end{array}$ \\
\hline Speech development & $\begin{array}{l}\text { Development of coherent speech and communication skills } \\
\text { Learning grammar elements }\end{array}$ \\
\hline $\begin{array}{l}\text { Artistic and aesthetic } \\
\text { development }\end{array}$ & $\begin{array}{l}\text { Reading comprehension } \\
\text { Constructive-modeling activity } \\
\text { Visual activity } \\
\text { Musical activity }\end{array}$ \\
\hline Physical development & $\begin{array}{l}\text { Development of initial ideas about a healthy lifestyle } \\
\text { Physical education }\end{array}$ \\
\hline
\end{tabular}

Source: Author's own elaboration

Within the context of these areas of remedial work, researchers highlight the various skills needed to prepare an autistic child for school. The development of these skills should be based on the accuracy of their assessment, the resources available to the child, as well as the areas of their future and current development. The future development area represents skills that require the joint activity of the child, parents, and teachers to be developed, whereas the skills already developed represent the current development area. 
Lavrentieva (2018) considers the development of prerequisites for learning behavior, meaningful reading, and writing skills, as well as initial writing skills that will be associated with these skill groups. In turn, Solomakhina, et al. (2017) discuss the need to develop communication, social, and everyday skills, as well as self-care skills. It is important to connect the skill groups identified by researchers with the content of the remedial work completed with the autistic preschooler. In this regard, the authors of this article decided to consider the skill groups: social and communication, hygiene and self-care (or life-care), academic (or general educational), organizational and behavioral. These skill groups have been arranged by the authors in a strict hierarchy according to their degree of importance in developing the cognitive sphere and social interactions in a child with ASD. Table 2 presents the groups of skills needed to prepare an autistic child for school; they are also correlated with the main areas of remedial work during the preschool period.

\section{Table 2}

Skills Developed as a Result of Remedial Work with Autistic Preschoolers

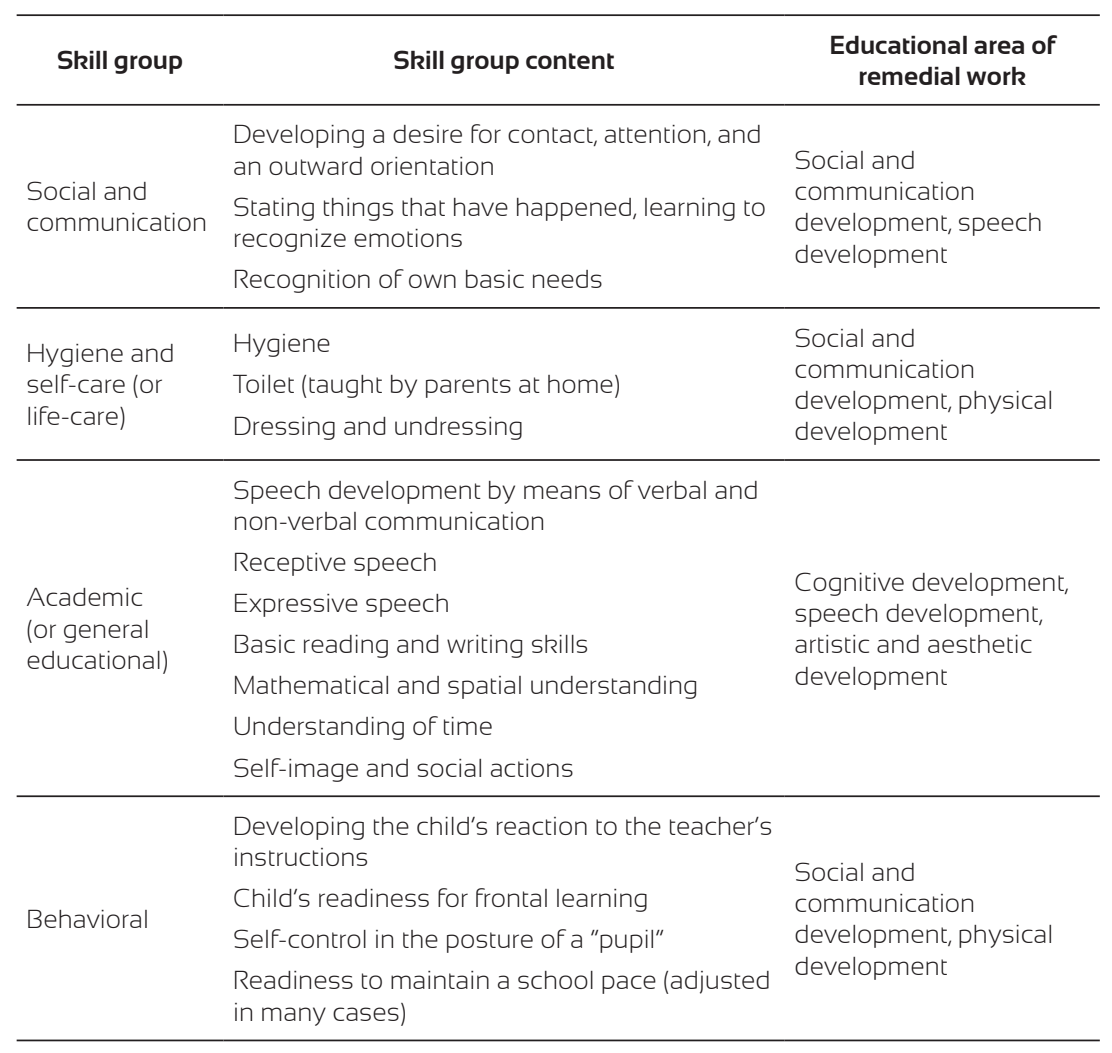


There are different opinions about whether PEIS are ready to organize remedial work in a timely manner. According to Turkish researchers from the Middle Eastern Technical University, D.N. Yazici and B. Akman, the majority of pedagogical workers are aware of the traits of ASD and welcome the inclusion of an autistic preschooler in the educational process. Learning with everyone contributes to the child's social interaction and the active involvement of the main participants in the educational process in remedial work. Specifically, if a child with ASD attends a PEI, pedagogical workers will prepare an appropriate EAP, will be able to know them better, will communicate more closely with their family, and will also inform other children and their families about learning with them (Yazici \& Akman, 2018, p. 105). However, Anderson, et al. (2018) argue that educators are not sufficiently prepared to provide the required support to the autistic child in accordance with their SEN. In this regard, they need to undergo refresher courses aimed at disclosing the characteristics of interacting with children with ASD after remedial work during the preschool period.

The main outcomes of remedial work with an autistic preschool child are, according to Japanese researchers, their social interaction and parental synchrony (Tachibana, et al., 2017, p. 28). Russian researchers agree. They looked at family support, since "the child's success directly depends on the parents' mental health and skills" (Dovbnya, et al., 2018, p. 157). In turn, researchers from Italy and the UK discuss the importance of parents' mental health, which is directly related to the level of emotional and behavioral disorders in an autistic child (Salomone, et al., 2018, p. 1189). These circumstances emphasize the need for individual support for the parents of an autistic child (Zheng, et al., 2019, p. 202), which takes the form of various methods of remedial work. It should be noted that there is no single system of effective methods for remediating and educating children with ASD in modern practice.

Specialists at the Institute of Remedial Pedagogy of the Russian Academy of Education (Moscow) offer the following methods for interacting with parents at Pels: conversation, journals, literary studies (books, movies). Accordingly, these methods imply discussing various subjects to create a more holistic picture of the world, recording life events and impressions of an autistic child, studying selected works of fiction, and acting out scenes from those works (Training and Methodological Center, 2018, pp. 50-51). The Guideline system, presented orally at evening advisory sessions or in writing (on flashcards or in special notebooks) every Friday, allows teachers and parents to coordinate. The guidelines in the notebooks instruct on how to organize a playdate at home, offer conversation topics, and provide EAP requirements (Training and Methodological Center, 2018, p. 51). 
At the "General Development Kindergarten No. 11" PEı in Maykop, methods used for studying a child and their parents are "questioning and observing the child, visiting the child's family, examining the family using projective techniques, talking with the child, talking with the parents, projective techniques (family drawing)" (General Development Kindergarten No. 11, 2016).

The Early Bird program, developed in the UK in 1997, aims to help children with ASD by educating their parents (National Autistic Society, 2019). The success of this program's introduction in Russia (initially in 2014, in the "Anton is Here" center, St. Petersburg) is confirmed by the frequent use of its recommended methods: visual support and structure, additional communication, approaches to analysis and behavior modification, etc. Implementing these methods can help overcome manifestations of "self-aggression, hysteria, difficulty sleeping, and using the toilet, ... it is more effective to engage with the child and improve their social skills" (Dovbnya, et al., 2018, p. 166). There is an increase in the level of social interaction associated with remedial work organized by a specialized center with the parents' participation.

There are also other methods for working with an autistic child, usually offered by specialized centers: art therapy (music, painting, movement, theater); dolphin therapy, pet therapy, hippotherapy, holding therapy, sensory integration, and applied behavioral analysis (ABA-therapy) (Sharapova, 2016).

Swiss researchers focus on the success of an autistic child as a result of systematic remedial work. However, that is insufficient if this work is not continued in the primary education system. According to Studer, et al. (2017), the gap between intensive remedial work and the actual school environment is enormous.

These methods are aimed at enhancing interaction with an autistic child after remedial work during the preschool period. Researchers offer a variety of methods for working with parents, promoted by both PEIS and specialized centers. Nevertheless, not every community has successfully functioning specialized remedial centers ready to render appropriate support to parents raising a child with ASD. Since PEIS are common everywhere, it is important to organize qualitative interactions between these three parties, the child, parents, and teachers at these institutions. It is the need to build effective interactions within this triad, within the context of PEIS, that drives the authors of this study to determine the available assessment methods for developing the skills necessary to prepare an autistic child for school after remedial work. 


\section{Research Methodology}

The content of the skill groups highlighted in the "Literature review and analysis" section represents the basic assessment criteria for determining the effectiveness of the interactions with an autistic child during the preschool period. This kind of assessment is particularly relevant in the older preschool years, since significant obstructions of neurological development will not allow an autistic child to continue to function during the school period. The main purposes of remedial work involve the interactions of such participants in the educational process as the child, parents, and teachers. Their coordinated work should be aimed primarily at developing the cognitive sphere and social interaction of the autistic child during the process of preparing for school.

The observational method is important to assess the development of skills that may be necessary to prepare an autistic child for school. Observation allows giving a student the psychological and pedagogical assessment necessary for further systematic remedial work at school. The assessment should consider the characteristics of the child's character, information about the family, and study place at home. The features of their cognitive activity and learning activities should also be described. The student's personal data is confidential information and cannot be presented in this article, in accordance with the Federal Law "On Personal Data" No. 152-FZ of July 27, 2006. Learning data from the study is only disclosed with the written consent of the parents.

For remedial work with an autistic child, it is important to use an effective method that ensures their SEN are satisfied during the preschool period. The journal method, which is designed to record the child's life events and impressions, is essential to the remedial work to be considered. It not only allows for events that occurred to be reproduced, but it also includes "value judgments, the expression of emotions and attitudes towards different events, phenomena, and people" (Training and Methodological Center, 2018). The journal reflects the following skills in accordance with the skill groups under study (see Table 3 ). 


\section{Table 3}

Content of Skill Groups Found in an Autistic Child's Journal

\begin{tabular}{|c|c|}
\hline Skill group & Manifested skill \\
\hline $\begin{array}{l}\text { Social and } \\
\text { communication }\end{array}$ & $\begin{array}{l}\text { Greeting when entering the classroom } \\
\text { Answering to greetings } \\
\text { Saying goodbye when leaving } \\
\text { Asking for help } \\
\text { Answering "Thank you" } \\
\text { Answering "I do not want" } \\
\text { Asking "Give me" } \\
\text { Saying "I want" } \\
\text { Waiting your turn to speak } \\
\text { Memory skills } \\
\text { Discussing what is happening } \\
\text { Preparing for an upcoming situation; } \\
\text { Choosing "good - bad" } \\
\text { Saying "Sorry, I forgot ..." } \\
\text { Saying "Sorry, I did not understand ..." } \\
\text { Recognizing the emotion of "joy" } \\
\text { Recognizing the emotion of "sadness" } \\
\text { Recognizing the emotion of "fear" } \\
\text { Recognizing the emotion of "anger" } \\
\text { Recognizing joy with laughter } \\
\text { Recognizing sadness with crying } \\
\text { Recognizing aggressive behavior } \\
\text { Recognizing fatigue } \\
\text { Recognizing hunger } \\
\text { Recognizing thirst }\end{array}$ \\
\hline $\begin{array}{l}\text { Hygiene and } \\
\text { self-care }\end{array}$ & $\begin{array}{l}\text { Distinguishing between hot and cold water valves } \\
\text { Regulating water pressure } \\
\text { Mixing water to a comfortable temperature } \\
\text { Wiping hands with a towel } \\
\text { Following the sequence of steps when washing and wiping hands } \\
\text { Following the sequence of steps when washing and wiping face } \\
\text { Following the sequence of steps when brushing your teeth and rinsing } \\
\text { Combing your hair } \\
\text { Recognizing (distinguishing) clothing items } \\
\text { Recognizing (distinguishing) clothing item details } \\
\text { Recognizing (distinguishing) shoes } \\
\text { Recognizing (distinguishing) head coverings } \\
\text { Distinguishing seasonal clothing } \\
\text { Unbuttoning } \\
\text { Undressing } \\
\text { Removing shoes } \\
\text { Following the sequence of steps when undressing } \\
\text { Following the sequence of steps when putting on an outfit }\end{array}$ \\
\hline
\end{tabular}




\begin{tabular}{|c|c|}
\hline Skill group & Manifested skill \\
\hline \multirow{7}{*}{ Academic } & Speech development through verbal and non-verbal communication \\
\hline & Receptive speech \\
\hline & Expressive speech \\
\hline & Basic reading and writing skills \\
\hline & Mathematical and spatial understandings \\
\hline & Understanding of time \\
\hline & Self-image and social actions \\
\hline \multirow{23}{*}{ Behavioral } & $\begin{array}{l}\text { Knows where the dressing room is; after arriving at school, goes to the } \\
\text { dressing room, to the correct place; hangs outerwear on the hanger, } \\
\text { changes shoes, also hangs shoe bag on a hanger }\end{array}$ \\
\hline & Picks up bag and goes to class \\
\hline & $\begin{array}{l}\text { Finds their seat in the classroom; gets the necessary items from their } \\
\text { backpack, according to the lesson; puts the backpack in the appropriate place }\end{array}$ \\
\hline & $\begin{array}{l}\text { In the classroom, sitting or moving in accordance with the teacher's } \\
\text { instructions during the lesson }\end{array}$ \\
\hline & After the lesson, changes textbooks and notebooks for the next lesson \\
\hline & $\begin{array}{l}\text { During recess, together with other students, under the guidance of a } \\
\text { teacher, leaves the classroom, walks to recess or goes to the cafeteria, to } \\
\text { the gym, to other classes, after school - goes to the dressing room }\end{array}$ \\
\hline & After class, collects all things in their backpack \\
\hline & May ask to use the toilet during the lesson (or at recess) \\
\hline & Can go to the toilet on their own during a break \\
\hline & Eats in the cafeteria \\
\hline & Performs the teacher's instructions \\
\hline & Looks at the teacher \\
\hline & Asks questions \\
\hline & Answers questions \\
\hline & Raises their hand when they know the answer \\
\hline & $\begin{array}{l}\text { Can, when asked by the teacher, leave their desk and answer at the } \\
\text { blackboard }\end{array}$ \\
\hline & Mimics what other students are doing if they missed what the teacher said \\
\hline & Communicates with peers at recess \\
\hline & Can write independently \\
\hline & Can open a textbook or notebook to the right place independently \\
\hline & $\begin{array}{l}\text { Not only uses a pen, but other stationery as well, in accordance with the } \\
\text { assignment }\end{array}$ \\
\hline & Seeks to improve their behavior or grade \\
\hline & Expresses varying degrees of interest in topics and lessons \\
\hline
\end{tabular}

Source: Author's own elaboration

To implement the journal method, we used a tool developed by Vinevskaya (2019), named "Journal for Parents of a Child with Special Needs." This method allowed not only tracking the presence and level of development of the skills necessary to prepare a child with autism for school, but also identifying areas of current and future development in the 
child (in other words, the development of skills and the need to develop skills involving joint activities with child, parents, and teachers, respectively). The "Journal for Parents of a Child with Special Needs" is provided by the school, completed by parents and reviewed by pedagogical workers to subsequently adjust parental interactions.

The "Guidelines for the Journal for Parents" are attached to the aforementioned document and explain the method of using the journal by describing the degree of skill development. There are several stages in using the journal. At the beginning of the school year, an autistic first grader's parents fill out initial data about the child, considering skill groups studied - this takes place after remedial work carried out during the preschool period. As the remedial work is done throughout the entire school year, parents note changes in skill development through scaling and feedback carried out regularly in oral and written forms. From the beginning of the school year, remedial work is directed strictly at developing skills in these groups: social and communication, hygiene and self-care, academic, and organizational-behavioral. At the end of the school year, parents submit material used to represent the skill groups developed (totally or partially) or undeveloped as a result of the remedial work.

The degree of manifestation of each skill studied is rendered on a threepoint scale: 2 - Developed (in other words, it is in the current development phase); 1 - Partially developed (in other words, it is in the child's future development phase); 0 - Undeveloped. This scaling allows performing several important assessment functions, namely: determining the child's current and future development area and identifying "partially-developed" skills, which must be developed in the future, and their nature. The assessment of a first grader with ASD takes place at the beginning of the school year to determine the effectiveness of their interactions after the remedial work under study. At the end of the year, another assessment is conducted to determine how successfully the parents' work was adjusted to develop the child's skills for school.

This study illustrates the results of the interactions within the child - parents - teachers triad in the example of a first grader with ASD during remedial work. The individual approach to preparing for school has been emphasized because of the specific characteristics of a child's neurological development and the need to represent individualized modes of interaction.

\section{Research Results}

At the beginning of the school year, using the observational method, a psychological and pedagogical profile was developed for a first-grade boy, V.V has been in the first grade since September 1, 2018. Before, he attended 
preschool for four years. Raised in a single-parent family, he is the firstborn child. His family lives in a two-bedroom apartment. The child is loved by all of his close relatives. $V$ receives a lot of attention from his mother. She is caring and kind to her son and is interested in his successful development.

The boy is kind, he is happy to meet visitors, and he looks well cared for. Development of major motor skills is age appropriate: he walks, runs, and jumps. The boy picks up after himself; he always knows where his things go. There are satisfactory conditions for learning activities at home. There is a study area (desk, textbooks, workbooks, pens, pencils, etc.). He gladly performs tasks in game form, preferring visual, building, and didactic games. The student has a good memory, he memorizes short poems easily and distinguishes between colors.

However, $\mathrm{V}$ does not focus on cognitive activity - He takes time processing things. When performing learning tasks, he cannot concentrate on work for a long time. He very quickly and abruptly switches from one activity to another and cannot plan his activities. In class, he is often distracted by external stimuli. The boy is greatly pained by experiencing the slightest failure or mistake - He abruptly becomes capricious (refuses to work, throws a pen, ruler, lies down on the table, and screams). However, when it comes to everyday things (for example, computer, games, Internet, television shows, toys) he shows keen interest.

At the time, $V$ does not show any specific desire to learn. He is slow and gets tired quickly. He has a low-level of learning activity and independence; he shows no desire in knowledge. His attention is involuntary and short-lived. It takes a long time for him to master even a small amount of material. It is not always possible to finish all of the material planned, since the child does not always accept the proposed tasks. Generalization operations are impossible because, sometimes, it is difficult to keep his attention long enough to arrive at the right answer. When performing tasks, he can only do them gradually, with help from the teacher and with constant approval and encouragement.

His fine motor skills are not perfectly developed. As first graders need help with writing and drawing, his writing skills are not fully developed - He can trace sample-letter shapes but is not able to color in pictures. The grammatical structure of his speech and pronunciation is broken. Currently, he can name all the letters with the help of the alphabet, and he is trying to put syllables together ( $A \cup, \cup A, A M, \cup M, M U)$, but has difficulty with pronunciation. He can count to around ten, but struggles to answer the question "How much?"

An analysis of the social and communication skill group shows that none of the 25 skills from the current development area are developed. At the beginning of the school year, $28 \%$ of the future development area skills

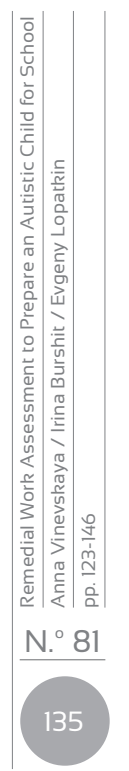


were developed, such as asking for help; asking "Give me"; the statement "I want"; recognizing the emotion of "sadness"; recognizing the emotion of "fear"; recognizing hunger; recognizing thirst. Thirty-six percent (36\%) appeared by the end of the school year, including the following skills: greeting when entering the classroom; answering to a greeting; saying goodbye when leaving; answering "I do not want"; waiting for their turn to speak, recognizing the emotion of "joy"; recognizing joy with laughter, recognizing sadness with crying, recognizing fatigue. Thirty-six percent (36\%) fell under undeveloped skills, including: answering "Thank you"; memory skills; discussing what is happening; preparing for an upcoming situation; choosing "good - bad"; the statement "Sorry, I forgot ..."; the statement "Sorry, I did not understand..."; recognizing the emotion of "anger"; recognizing aggressive behavior.

Scaling used for developed skills recorded in the "Journal for Parents of Children with Special Needs" is presented in figures that reflect the development dynamics of the skill groups under study after remedial work. The development dynamic in the socio-communication skill group at the end of the school year is represented in Figure 1.

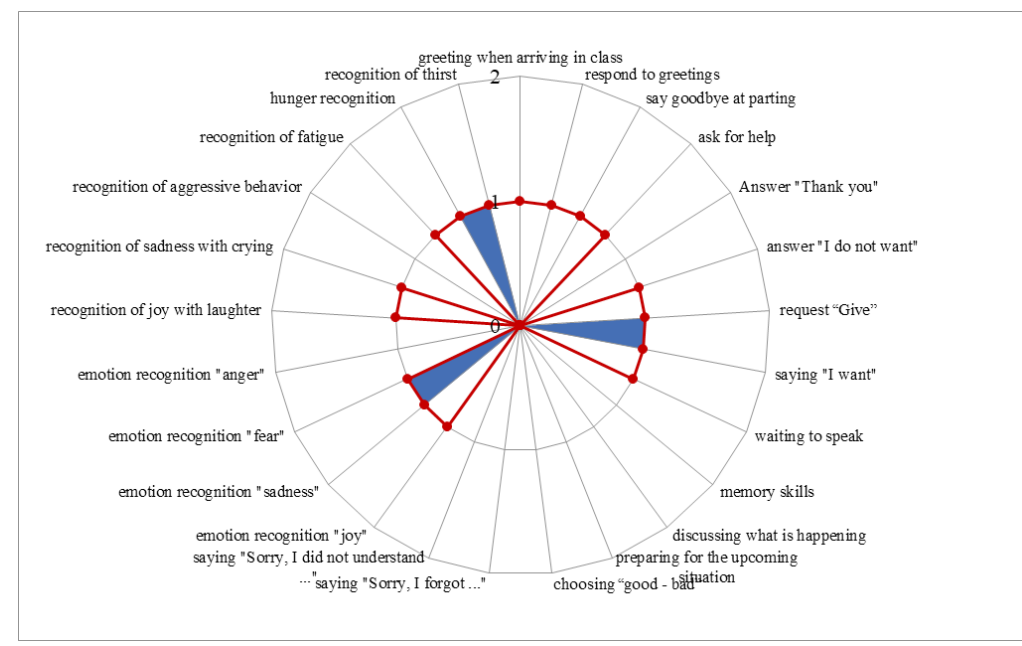

Fig. 1. The Development Dynamic of the Socio-Communicative Skills Group in a First Grader with ASD

Analysis of the development of the hygiene and self-care skill group indicates the manifestation of all 18 skills under study, with partial development of $38.9 \%$ of non-dynamic skills, and $61.1 \%$ of dynamic skills. Specifically, the earlier-developed skills in the future development area 
include wiping hands with a towel; following the sequence of steps when washing and wiping hands; following the sequence of steps when brushing teeth and rinsing; combing hair; recognizing (distinguishing) clothes; unbuttoning and undressing. The development dynamic of skills in the future development area includes distinguishing between hot and cold water valves; regulating water pressure; mixing water to a comfortable temperature; following the sequence of steps when washing and wiping their face; recognizing (distinguishing) clothing items; recognizing (distinguishing) shoes; recognizing (distinguishing) head coverings; distinguishing between seasonal clothing; removing shoes; following the sequence of steps when undressing; following the sequence of steps when getting dressed. None of the skills are fully developed and, therefore, cannot be placed in the current development area.

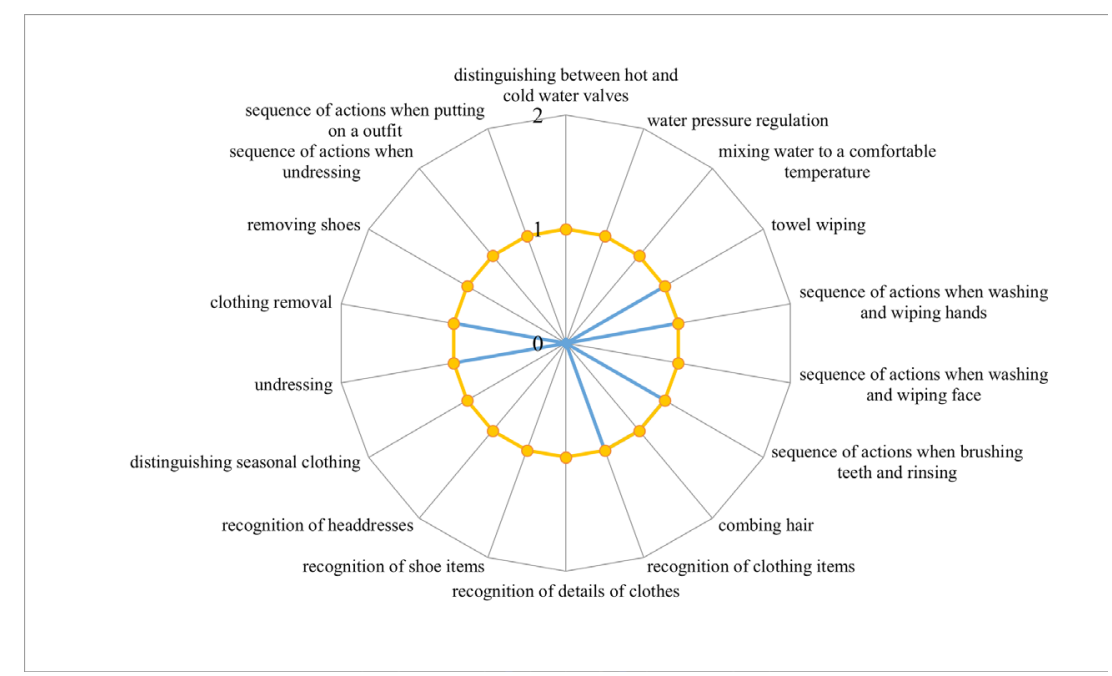

Figure 2. Presents data on the development dynamic of the hygiene and self-care skill group from the beginning to the end of the first school year

After analyzing the development of the third group of skills (seven total), the following was revealed. There were no fully developed skills in the academic skill group, i.e. in the current development area. However, the future development area includes such skills as speech development through verbal and non-verbal communication; receptive speech; expressive speech; and mathematical and spatial understanding, which fail to show dynamics $(50 \%)$. The current development area also includes initial reading and writing skills, as well as self-image and social actions, which have a development dynamic (33.3\%). Understanding of time $(16.7 \%)$ is undeveloped. 
The data in Figure 3 presents the development dynamic for the academic skill group during the school year.

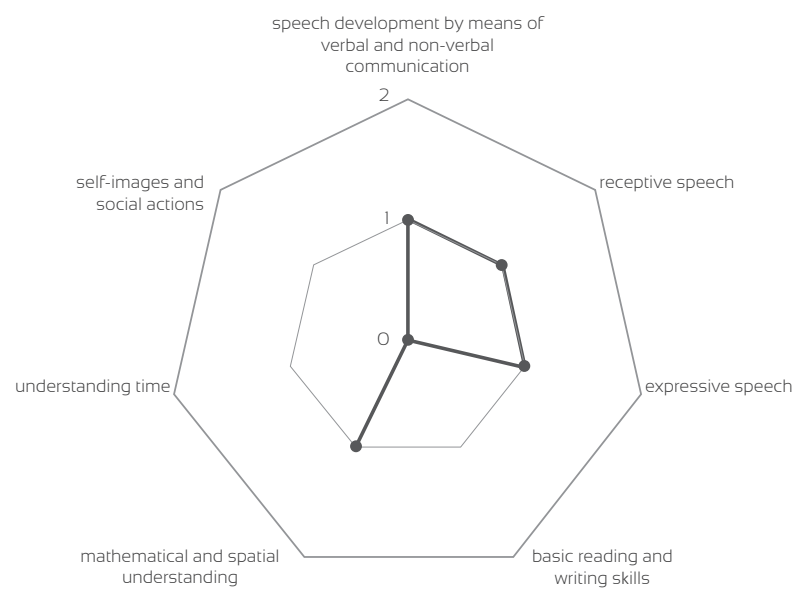

Fig. 3. The Development Dynamic of the Academic Skills Group in a First Grader with ASD

Analysis of the group of 24 organizational and behavioral skills at the beginning and end of the school year indicated a greater number of undeveloped skills in comparison with other groups of study. The $65.2 \%$ of these undeveloped skills included:

» Knows where the dressing room is; goes to the dressing room after arriving at school, to the correct place; hangs outerwear on the hanger, changes shoes, also hangs shoe bag on hanger

»In the classroom, finds their seat; gets necessary things from backpack for the lesson; backpack is placed in the appropriate place

» After the lesson, changes textbooks and notebooks for the next lesson

»After classes, puts all things in their backpack

¿Eats in the cafeteria

» Performs the teacher's instructions

» Looks at the teacher

»Asks questions

» Raises hand when they know the answer

"Can, at the teacher's request, leave their desk and answer at the blackboard

» Communicates with peers during breaks

»Can write independently

»Can open a textbook or notebook to the correct place independently 
» Not only uses a pen, but other stationery as well, in accordance with the assignment

» Seeks to improve their behavior

The other $34.8 \%$ of the skills are in the future development area, with all partially developed skills with dynamics at the end of the school year, including:

» Picks up backpack and goes to class

» Is in the classroom, sitting or moving in accordance with the teacher's instructions during the lesson

» During recess, together with other students under the supervision of a teacher, leaves the classroom, walks to recess or goes to the cafeteria, to the gym, to other classes, after school - goes to the dressing room

» During the lesson (or at recess) may ask to use the toilet

» Can go to the toilet on their own during a break

»Answers questions

» Mimics what other students are doing if they missed what the teacher said

» Seeks to improve behavior or grade

» Expresses varying degrees of interest in topics and lessons

Figure 4 presents the development dynamic of the organizational and behavioral skill group at the beginning and end of the school year.

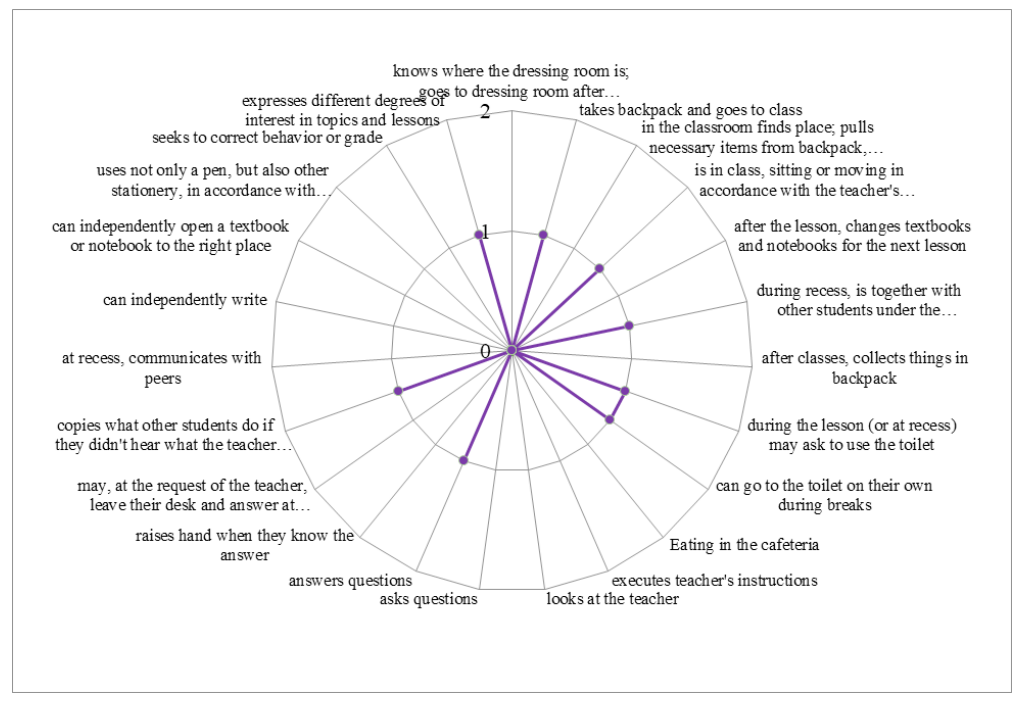

Fig. 4. Development Dynamic of the Organizational and Behavioral Skills Group in a First Grader with ASD 


\section{Interpretation of Research Results}

The psychological and pedagogical characteristics of the student with ASD show that his cognitive skills are not sufficiently developed and his academic knowledge and skills do not correspond to the standard for his age. The boy has repressed emotions, seems moody, is acting stubborn, and is quick to cry. He is only interested in talking about everyday issues. His attention is passive, diffuse, unstable, easily distracted, involuntary. His attention span is insufficient and incomplete. The boy can do written and counting exercises with direct help from the teacher. $V$ needs constant supervision, as well as all types of assistance. Therefore, the psychological and pedagogical characteristics of this autistic first grader justify the need for implementing systematic remedial work.

Analyzing the skill groups developed by $\mathrm{V}$ for school confirms the effectiveness of triad interaction (child - parents - teaching staff) after remedial work. These conclusions correspond to the positions stated in this study's research hypothesis, since, in total, a development dynamic was indicated in $40.54 \%$ of all the skills distributed throughout the groups (dynamics in 30 out of 74 total skills in the groups).

The results obtained indicate the need to continue remedial work, as there are no dynamics in $24.32 \%$ of developed skills in the future development area (18 out of 74 total skills in the groups). Specifically, pedagogical workers need to strengthen remedial work on the undeveloped skills, totaling $35.14 \%$ (26 out of 74 total skills in the groups).

Parents usually associate the social and communication skill group in autistic children with skills developed based on the residual principle. This is due to the fact that parents have some understanding about the development of hygiene and self-care skills, as well as academic skills. It is difficult, time and energy-intensive, to form social and communication skills, so parents hope these skills take shape at school with the help of teachers or that the child, amid their peers, will automatically become master communicators. Of course, hygiene and self-care skills should be developed even before school. However, practice shows that parents miss many skills or incompletely develop them because they pay more attention to other skills, which they personally consider as the most significant.

Academic skills must be developed before a child enters school by pedagogical workers who are approached by the parents during the remedial work under study. If these skills are already developed, the pedagogical worker needs to pay attention to their integrated use in educational activities. If gaps are observed in the list of skills (for example, "partially-developed" organizational and pedagogical skills), the 
pedagogical worker needs to focus on including basic elements to integrate the missing skill with other skills. For example, here it is appropriate to use words indicating a number of objects ("five", "second", etc.) and words indicating the locations of objects/subjects ("on the table"; "near the house"; "on the top shelf", etc.): "Grab the five sticks on the table"; "Find three dolls on the top shelf." Mastering understanding of time is considered a difficult skill to develop.

This research enriches remedial work with autistic children in the absence of officially developed EAPS. This involves developing skills in the future and current development areas that are necessary to prepare the child for school. In this regard, keeping a journal that details the development of the selected skill groups and their subsequent assessment enhances remedial work.

To continue remedial work, it is appropriate to use the Floortime strategy and the emotional-semantics approach, which are recommended by researchers from the Institute of Remedial Pedagogy of the Russian Academy of Education (Moscow). Each of these approaches focuses on developing the child's emotional relationships with their parents and teachers, once the task of developing their emotional experience has been completed. The extent to which this experience is developed determines an autistic child's options for active and meaningful interactions with their environment. Both methods are guided by the laws on developing emotional interactions with a child, methods for establishing emotional contact, and understanding the full nature of this experience. However, the emotional-semantics approach focuses on the sequential introduction of qualitatively differing experiences in a child's life and concentrates on the role of parents and teachers in sharing experiences with the child (Nikolskaya, et al., 2019, p. 141).

A researcher from Liverpool (UK) focuses on the effectiveness of the Montessori pedagogical approach for teaching children with ASD during preschool. This approach includes developing self-regulation skills and, accordingly, changes in student behavior. It is important to include game methods based on this approach in the appropriate EAPs (Marks, 2016, p. 313).

Information and communication technologies can help shape "partially-developed" skills of autistic children. Since uniformity of action is a key student trait, these technologies offer a similar uniformity. This is one of the reasons why autistic children prefer to communicate with devices, instead of people (Abidoğlu, et al., 2017, pp. 4958-4959). Autistic children use software that is designed specifically for students with ASD that accounts for differences in skill development in accordance with age characteristics and interests. 


\section{Conclusions}

The study was designed to assess remedial work, which allows easing disorders in children with autism spectrum disorder based on their childhood neurological development. Constant remedial work with autistic children in a preschool educational institution should be implemented jointly with the relevant educational adjusted program, creating the conditions to develop their cognitive sphere and increase social interactions. Under these conditions, the main guidelines of remedial work with an autistic child during preschool are arranged by educational area: social and communication development, cognitive development, speech development, artistic and aesthetic development, and physical development. Under these educational areas, the social and communication, hygiene and self-care, academic, and organizational and behavioral skill groups were studied. In the context of a preschool educational institution, development in the selected skill groups occurs by building regular interactions between the child - parents - teachers triad.

Preparation methods are needed to assess skill development to prepare an autistic child for school after remedial work. This research method helped draw a psychological and pedagogical picture of a first-grade autistic boy using observation. Skill development was also monitored, and the child's future and current development areas were identified after analyzing their "Journal for Parents of Children with Special Needs".

This research determined the effectiveness of interactions with an autistic child after remedial work during the preschool period. His psychological and pedagogical characteristics justify the need for implementing systematic remedial work for an autistic first grader, since an assessment of development in the skill groups required for schooling in the autistic first grader confirms the effectiveness of interactions in the triad. These conclusions confirm the positions stated in this study's research hypothesis, since, in total, a development dynamic was noted in $40.54 \%$ of all the skills distributed in the groups

The results of the study are valuable for the pedagogical community, not only in preschool educational institutions, but also in primary schools. Assessing the effectiveness of remedial work is important for an autistic child both at the beginning of their first school year and at the end of it. This assessment, based on the "Journal for Parents of a Child with Special Needs", was done using a rather extensive set of skills, divided into four groups: social and communication skills, hygiene and self-care skills, academic skills, and organizational-behavioral skills. They should all be considered by the pedagogical community to make timely adjustments when working with an autistic child. 
The study is limited by the fact that the experience of triad interactions was only observed in one child with autism. The authors of the article plan to conduct a large-scale study that considers the differences in neurological development in children using the observational method and journals. Nevertheless, the results obtained indicate the need to continue remedial work. During remedial work, there should be a focus on developing a desire within parents to cooperate with teachers and actively introduce their child into society.

\section{References}

Abidoğlu, Ü. P., Ertuğruloğlu, O., \& Büyükeğilmez, N. (2017). Importance of computer-aided education for children with autism spectrum disorder (ASD). EURASIA Journal of Mathematics Science and Technology Education, 13(8), 4957-4964. doi: 10.12973/eurasia.2017.00975a

General Development Kindergarten No. 11. (2016). Adaptirovannaja obrazovatel'naja programma dlja detej s RAS municipal'nogo bjudzhetnogo doshkol'nogo obrazovatel'nogo uchrezhdenija "Detskij sad obshherazvivajushhego vida No 11» na 2016-2017 uchebnyj god [Adjusted Educational Program for Children with ASD of the Municipal Budgetary Preschool Educational Institution "General Development Kindergarten No. 11" for the 2016-2017 academic year]. http://mbdou11 maykop.ru/attachments/article/245/Adaptirovannaja obrazovatel'naja programma dlja detej s RAS (Abdurahmanova Z.H.docx).

Anderson, C. M., Smith, T., \& Wilczynski, M. (2018). Advances in schoolbased interventions for students with autism spectrum disorder: Introduction to the special issue. Behavior Modification, 42(1), pp. 3-8. doi: 10.1177/0145445517743582

Boekhof, E., Ketelaar, L., Stockmann, L., Zijp, A. van, Bos, M. G. N., \& Rieffe, C. (2015). The understanding of intentions, desires and beliefs in young children with autism spectrum disorder. Journal of Autism and Developmental Disorders, 45, pp. 2035-2045. doi: 10.1007/ s10803-015-2363-3

Don, G.V. (2017) Uslovija obrazovanija detej doshkol'nogo vozrasta, imejushhih RAS, v gruppe kratkovremennogo prebyvanija // Autizm i narushenija razvitija. [Conditions for the education of preschool children with ASD in the short-term stay group // Autism and developmental disorders] 15(4), pp. 16-25. doi: 10.17759/autdd.2017150403

Dovbnja, S., Morozova, T., Zalogina, A., Monova, I. (2018). Deti s rasstrojstvami autisticheskogo spektra $v$ detskom sadu i shkole: praktiki s dokazannoj jeffektivnost'ju [Children with autism spectrum disorders in kindergarten and school: practices with proven efficacy]. Fund "Naked Heart". 
Ministry of Education and Science of the Russian Federation (2013). Federal'nyj gosudarstvennyj obrazovatel'nyj standart doshkol'nogo obrazovanija [Federal state educational standard of preschool education.]. https://pravobraz.ru/federalnyj-gosudarstvennyj-obrazovatelnyj-standart-doshkolnogo-obrazovaniya/

Academy of Professional Development. (2018, January 15) Inkljuzija v DOU: po kakoj programme uchit' detej? [Inclusion in preschool: what program to teach children?]. Academy of Professional Development. https://academy-prof.ru/blog/adaptirovannaja-obrazovatelnaja-programma-v-do

Lavrentieva, N. B. (2008). Podgotovka k shkol'nomu obucheniju detej s autizmom // Al'manah Instituta korrekcionnoj pedagogiki. [Preparing children with autism for schooling // Almanac of the Institute of Corrective Pedagogy]. (12). https://alldef.ru/ru/articles/almanah-12/ podgotovka-k-shkolnomu-obucheniyu-detej-s-autizmom

Marks, L. (2016). Playing to learn: An overview of the Montessori Approach with preschool children with Autism Spectrum Condition. Support for Learning, 31(4), pp. 313-328. doi: 10.1111/1467-9604.12140

Mclntyre, L. L. \& Zemantic, P. K. (2017). Examining services for young children with autism spectrum disorder: Parent satisfaction and predictors of service utilization. Early Childhood Education Journal, 45(6), 727-734. doi: 10.1007/s10643-016-0821-y

National Autistic Society (2019). EarlyBird. Retrieved from: https://www. autism.org.uk/services/comm

Nikol'skaja, O. S., Baenskaja, E. R., Guseva, I. E. (2019) Zadachi i metody korrekcionnoj pomoshhi rebenku s autizmom // Konsul'tativnaja psihologija i psihoterapija [Tasks and Methods of Corrective Help for a Child with Autism // Consultative Psychology and Psychotherapy]. 27(1), pp. 140-152. doi: 10.17759/cpp.2019270109

Training and Methodological Center - "Center for the implementation of FGOS". (2018). Проект примерной адаптированной основной образовательной программы дошкольного образования на основе фгос дошкольного образования для детей раннего и дошкольного возраста с расстройствами аутистического спектра [Draft of an Adjusted Model of a Basic Education Program for Preschool based On FSES PE for early childhood and preschool children with autism spectrum disorders]. http://fgosovz24.ru/assets/files/novosti/ praoop-do-obuchayushhihsya-sras_2_1.pdf

Salomone, E., Leadbitter, K., Aldred, C., Barret, B., Byford, S., Charman, T., Slonims, V. (2018). The association between child and family characteristics and the mental health and wellbeing of caregivers of children with autism in mid-childhood. Journal of Autism and Developmental Disorders, 48(4), 1189-1198. doi: 10.1007/s10803-017-3392-x 
Sharapova, Ju. V. (2016, January). Rekomendacii po rabote $s$ autistami. Social'naja set' rabotnikov obrazovanija nsportal.ru. [Recommendations for working with autists. Social network of educators nsportal. ru.]. https://nsportal.ru/detskiy-sad/raznoe/2016/01/18/rekomedatsii-po-rabote-s-autistami

Solomahina, T. N., Fajzulaeva, R. R., Mihaleva, I. M., Artem'eva, N. V., Shevchenko, E. V. (2017). Osobennosti korrekcionno-razvivajushhej raboty s det'mi s rannim detskim autizmom i drugimi rasstrojstvami autisticheskogo spektra v uslovijah DOU // Molodoj uchenyj [Features of remedial and developmental work with children with early childhood autism and other autism spectrum disorders in conditions of preschool educational institution // Young scientist]. (42), pp. 178180. https://moluch.ru/archive/176/46008/

Studer, N., Gundelfinger, R., Schenker, T., \& Steinhauser, H.C. (2017). Implementation of early intensive behavioral intervention for children with autism in Switzerland. BMC Psychiatry, 17(34), 1-10. doi: 10.1186/s12888-017-1195-4

Tachibana, Y., Miyazaki, C., Ota, E., Mori, R., Hwang, Y., Kobayashi, E., Kamio, Y. (2017). A systematic review and meta-analysis of comprehensive interventions for preschool children with autism spectrum disorder (ASD). SENS One, 12(12): e0186502, 1-28. doi: 10.1371/journal. pone.0186502

Teh, E. J., Yap, M. J., \& Liow, S. J. (2018). Emotional processing in autism spectrum disorders: Effects of age, emotional valence, and social engagement on emotional language use. Journal of Autism and Developmental Disorders, 48(12), 4138-4154. doi: 10.1007/s10803018-3659-x

Vinevskaya, A. V. (2019). Dnevnik dlja roditelej detej s OVZ i invalidov [Journal for Parents of a Child with Special Needs]. Moscow: Pero.

Yazici, D. N. \& Akman, B. (2018). An investigation of preschool teachers' opinions about the inclusion of children with autism. Ankara Universitesi Egitim Fakultesi Ozel Egitim Dergisi-Ankara University School of Educational Sciences Journal of Special Education, 19(1), 105-128. doi: 10.21565/ozelegitimdergisi.284253

Zheng, L. D., Grove, R., \& Eapen, V. (2019). Predictors of maternal stress in preschool and school-aged children with autism. Journal of Intellectual \& Developmental Disability. 44(2), 202-211. doi: 10.3109/1 3668250.2017 .1374931 